\title{
m-RNA profiling of HSP-70 under different tropical stress conditions in various broilers
}

\author{
S. A. Amrutkar, V. K. Saxena and S. Tomar
}

Department of Animal Genetics and Breeding,

Central Avian Research Institute, I zatnagar- 243122, Uttar Pradesh, India

Corresponding author: S. A. Amrutkar, email: suraj_amrutkar@rediffmail.com; Tel: +91-8872884528

Received: 05-12-2013, Revised: 25-01-2014, Accepted: 28-01-2014, Published online: 28-02-2014

doi: $10.14202 /$ vetworld.2014.100-107

How to cite this article: Amrutkar SA, Saxena VK and Tomar S (2014) m-RNA profiling of HSP-70 under different tropical stress conditions in various broilers, Veterinary World 7(2): 100-107.

\begin{abstract}
Aim: The present experiment was conducted to study the effect of different tropical stress conditions on haemato-biological traits in various broiler strains during 3 to 4 weeks of age. Introgressing some important major genes likes Naked neck ( $\mathrm{Na}$ ) and Frizzle $(F)$ into broiler germplasm may substantially improve the heat tolerance.

Materials and Methods: The experiment was designed to evaluate three indigenously developed broilers viz. CARIBROTropicana (Naked neck and Frizzle gene bearing), CARIBRO-Mritunjai (Naked neck gene bearing) and CARIBRO-Vishal (Normal plumaged) under different THI (i.e. 72, 85 and 91) for 4 hours daily for 7 days. Total 324 broiler chicks (i.e. 36 chicks in each group) of 3 weeks of age were used in this study.

Results: The m-RNA expression of HSP-70 gene was observed highest in frizzle plumaged birds and lowest in normal plumaged birds. The CARIBRO-Vishal showed highest stress as compared to other group. Higher the THI more severe was the effect on the traits. During the 7 day of exposure trial birds of all the genetic group exhibited the phenomenon of acclimatization as reveled by the averages of various traits at different days into the exposure. The mRNA expression analysis of $\mathrm{HSP}-70$ in liver revealed higher expression levels at later days during the exposure trials which indicated the phenomenon of memory (stress memory) and acquired thermotolerance.
\end{abstract}

Conclusion: Among the three genetic groups, CARIBRO-Tropicana exhibited highest means for HSP-70 production as well as tolerated the heat stress in a better way; therefore CARIBRO- Tropicana was adjudged to be the best genetic group for production under tropical climate.

Keywords: broiler, HSP-70, mRNA, tropical stress.

\section{I ntroduction}

The center of poultry industry is shifting to subtropical countries and this trend is likely to continue. Nearly one third of world-wide broiler stock placement is in Asian countries such as India and china and these countries are emerging as important locations for the production and trade of poultry product, whereas, the major international poultry breeders are located in temperate countries. India has distinctly different seasons with variable temperature and humidity. The high ambient temperature in tropical climate leads to heat stress to poultry in general and to broilers in particular. Heat stress results in poor performance in growth, feed efficiency and meat yield as well as higher mortality. Recent decades have seen significant developments in genetic selection of the meat type fowl, i.e. Broilers [1, 2] and Turkeys [3]. The genetic selection has led to rapid growth accompanied by increased feed efficiency and metabolic rate [4], thus providing the poultry industry with heavy domestic fowls in relatively short growth period. Such development in body size logically necessitates increase in the

Copyright: The authors. This article is an open access article licensed under the terms of the Creative Commons Attribution License (http://creativecommons.org/licenses/by/2.0) which permits unrestricted use, distribution and reproduction in any medium, provided the work is properly cited. size and efficiency of the cardiovascular and respiratory system. However, relatively inferior development of such major body systems [3] has led to lower ability for balancing energy expenditure and body water content under extreme environment conditions. Thus, acute exposure of chickens to extreme conditions results in major economic losses.

All living organisms possess surveillance and homeostatic mechanisms to adjust the demand of growth, differentiation, environmental stress and ageing. However, under certain circumstances, these mechanisms fail to adequately respond to imbalanced and result in the accumulation of the misfolded proteins inside the cell.

To adapt to these environmental challenges and survive different types of injuries, cells have evolved networks of different responses which detect and control diverse form of stress. One of these responses, known as the heat shock responses (HSR), has attracted a great deal of attention as a universal fundamental mechanism necessary for cell survival under a variety of unfavorable conditions. The heat shock response is transient and lasts only a few hours [5]. This phenomenon of HSR is a very well conserved regulatory network across all eukaryotes and is triggered by the synthesis of a group of proteins [6]. 
The utilization of major genes for broiler production under tropical conditions exudes much enthusiasm among the poultry breeders. The important major genes are Naked neck $(N a)$, Dwarf $(d w)$ and Frizzle $(F)$. These genes are located on Autosomes and get inherited in Mendelian fashion. Introgressing some important major genes into the poultry germplasm may substantially improve the heat tolerance ability of broilers without reducing their economic performance. Some major genes results in reduction of feather cover while other exerts their effect by decreasing the metabolic heat output $[7,8]$.

In prokaryotic and eukaryotic cells, the synthesis of specific stress proteins increases under a wide variety of stress conditions. The most extensively investigated stressors is heat stress in which, a sudden increase in temperature induces the synthesis of heat shock proteins (HSPs) [9]. The role of HSPs in the protection of cells from heat stress is well established. An important aspect of HSPs is that organisms which have reversed from previous mild stressful conditions expresses elevated level of stress proteins [10]. HSPs work as molecular Chaperones. These stress proteins can exhibit tolerance against the high levels of the stress causing agents, including heat that would normally cause developmental abnormalities or death [10]. This phenomenon, referred as "Acquired thermotolerance" which is dependent on the increased expression and accumulation of the HSPs [11]. Various families of HSPs are named according to their approximate molecular weight i.e. $8,28,58,72,90$ and $110 \mathrm{KDa}$, hence referred as HSP 8, HSP 28, HSP 60, $H S P$ 70, HSP 90 and HSP 110. HSPs are required to withstand the toxic effects of extreme temperatures. These proteins also play role in immunity and immunopathology [12]. Heat shock proteins are induced by a variety of agents including stressors. Heat is the most prominent inducer of HSPs. Heat pre-conditioning is related to the expression of HSPs and antioxidant enzymes [21]. HSP-70 expression levels could be influenced by the cold stress and the expressions levels differed in different tissues in different durations of the cold exposure [22]. Neonatal feed restriction improved $H S P-70$ expression in aged birds [23]. Pituitary and thyroid $H S P-70$ m RNA transcription level was repressed which showed that it was the down regulation genes of pituitary and thyroid in cold stress reaction [24]. The effect of stresses did not produce any significance effect on mRNA expression of $H S P-70$ in ovary and ovarian follicles of Japanese quail at 6 week old age [25]. The response of $H S P-70$ was greater in the high fear than the low fear group. Both low fear and high fear showed similar increases in HSP-70 expressions after crating [26]. Heat stress increases the level of HSP-70 in brain and ovary [27]. Serum levels of HSP-70 in broiler chickens also increased after continuous feeding of sodium arsenite in drinking water. This particular observation may be attributed towards systematic inflammation, oxidative stress and hepatocellular injury [28]. Open sided House birds had greater $H S P-70$ expression than the environmentally controlled House; the feed restriction chicks showed higher HSP-70 density than those of ad libitum feed groups [29]. The positive signals of $H S P-70 \mathrm{mRNA}$ at $6 \mathrm{hr}$ heat stress were localized in the liver and lung, especially in the walls of vessels. The weak positive signals were seen in the myocardial cells. No significant singles were observed in spleen, thymus and bursa of fabricius [30]. The liver samples for $H S P-70$ expression concluded that during stress $\left(40{ }^{\circ} \mathrm{C}\right.$ temperature for 2 hrs) a non-significant ( $\mathrm{P}>0.05)$ induction of HSP-70 expression was observed in turkey embryo [31]. The cells with increased HSPs exhibit tolerance against the additional stress hence they are often called as stress markers [32]. Subjected to cold or high incubation temperature, the expression of $H S P-70$ in younger embryos had higher $H S P$ - 70 synthesis than older embryos [17]. The moderate heat stress caused significantly increased $H S P-70$ levels compared with the control groups in 51 and 65 weeks laying hens [33]. Resistance to acute heat stress and concentration of $H S P$-70 were higher in those birds subjected to more heat stress in broilers [34]. During heat stress $\left(35^{\circ} \mathrm{C}\right)$, the increase in both colonic temperature and hepatic $H S P-70$ concentration were significantly less in high energy fed broilers [35]. The oxidative stress has been proposed as a key mechanism that mediates HSPs induction [36]. HSPs regulate cellular functions by playing institutive roles in protein folding, unfolding, assembling, disassembling and translocation [37-40].

In view of the above the present investigation was carried out to evaluate the normal, Naked neck and Frizzle plumaged broiler strains developed at Central Avian Research Institute (CARI), Izatnagar under different thermal humidity indices using functional genomics tools in order to throw light on underlying physiological and genetic mechanism in major genes ( $\mathrm{Na}$ or $\mathrm{F}$ gene) induced heat tolerance in broiler chicken. The present study was under taken with the objectives to undertake mRNA profiling of $H S P-70$ under different tropical stress conditions in various broilers strains

\section{Materials and Methods}

Ethical approval: Authors followed all the national legislation concerning protection of animal welfare and following the guidelines of the Ethics Committee. This work is approved by the permission of Director, Institutional Animal Ethics Committee, Indian Veterinary Research Institute(IVRI).

Experimental site: The proposed research work was conducted at Experimental Broiler Farm and Disease Genetics \& Biotechnology Lab, Division of Avian Genetics and Breeding, CARI, Izatnagar. The trials for exposure of chicks under different THIs were carried out in Psychometric chamber, Veterinary Physiology Division, IVRI.

Germplasm: The CARIBRO-Mritunjai (Necked neck 
Table-1. Formula and chemical composition of broiler rations.

\begin{tabular}{llll}
\hline Sr. No. & Ingredients & Starter\% & Finisher\% \\
\hline 1 & Maize & 58.805 & 59.5 \\
2 & Soyabean & 28 & 26 \\
3 & Sunflower meal & 5 & 2.5 \\
4 & Fish meal & 5 & 3 \\
5 & Limestone & 1 & 0.8 \\
6 & Di-calcium phosphate & 1.5 & 1.1 \\
7 & Salt & 0.2 & 0.2 \\
8 & DL- Methionine & 0.06 & 0.04 \\
9 & Trace mineral Premix & 0.1 & 0.1 \\
10 & Vitamin premix & 0.15 & 0.15 \\
11 & Vitamin B complex** & 0.015 & 0.015 \\
12 & Choline Chloride & 0.05 & 0.05 \\
13 & Toxin Binder & 0.05 & 0.05 \\
14 & Protexim & 0.02 & - \\
15 & Coccidiostat & 0.05 & 0.05 \\
16 & De-oiled Rise Bran & - & 1.42 \\
17 & Rape seed meal & - & 5 \\
18 & Lysine & - & 0.02 \\
& Total & 100 & 100 \\
Nutrient Composition & Crude Protein(\%) & 18.98 \\
& Metabolizable Energy; ( Kcal /Kg) ${ }^{* * *}$ & 2843 & 2850 \\
& Calcium (\%) & 1.17 & 1.17 \\
& Available Phosphorus (\%) & 0.496 & 0.5 \\
& Lysine (\%) & 1.24 & 1.22 \\
\hline
\end{tabular}

* Trace mineral Premix: Mg-300, mn-55,I-0.4, fe-56, $\mathrm{Zn}-30$ and $\mathrm{Cu}-4 \mathrm{~kg}^{-1}$

** Vitamin premix: Vitamin A-8250 IU, Vitamin D3$1200 \mathrm{ICU}$, Vitamin k-1mg, Vitamin E-40 IU, Vitamin $B_{1}-2 m g$, Vitamin $B_{2}-4 m g$, Vitamin $B_{12}-10$ mcg, Percent of values specified by NRC, 1994, *** Calculated plumaged), CARIBRO-Tropicana (Naked neck and Frizzle plumaged) and CARIBRO-Vishal (normal plumaged) broiler chicks developed at Experimental Broiler Farm, Central Avian Research Institute, Izatnagar, were used in this study.

Reagents: All the chemicals, reagents and kits from standard manufacturers like Fermentas, Quiagen, and Invitrogen and of appropriate grade were used for analyzing various parameters. Molecular biology grade chemicals were used for the preparation of buffers and solutions throughout the experiment in autoclaved distilled/ Milli Q water. The buffers and reagents used in RNA work were prepared in Di-ethylpyrocarbonate (DEPC) treated distilled water using nuclease free molecular biology grade chemicals.

Equipment: Cooling micro-centrifuge (3500 Table top micro refrigerated centrifuge, Cubota Corporation, Tokyo, Japan), Tissue homogenizer (Polytron, Kinematica AG, Switzerland), Micropipettes (Eppendorf AG, Germany), Nano drop-1000 (Thermo Scientific, Singapore), Thermal cyclers (iQ5 Multicolor Realtime PCR Detection System; iCycler, MJ Mini Gradient Thermal Cycler, Bio- Rad laboratories, Inc. Hercules, USA), Gel documentation system (Biometra, UK; Syngene, USA), horizontal submarine electrophoresis apparatus (Scie-Plas Ltd., Warwickshire, England), Laminar air- flow apparatus (Tanco, India). Auto Gamma counter (COBRA III, Packard Bio Science), Double beam UV-VIS spectrophotometer (ICI, India).

Glass and plastic wares: Glass wares i.e. beaker, test tubes, cylinders, and conical flasks, round bottle flasks etc. used throughout the experiment were acquired from Borosil (India). Plastic wares viz. real time PCR tubes and flat caps, microcentrifuge tubes $(0.2 \mathrm{ml}, 1.5$ $\mathrm{ml}$ and $2 \mathrm{ml})$ and tips $(20 \mu \mathrm{l}, 200 \mu \mathrm{l}$ and $1 \mathrm{ml})$ were procured from axygen (USA). Falcon tubes ( $15 \mathrm{ml}$ and $50 \mathrm{ml}$ ) were purchased from Axygen (India).

Chemicals and kits: TRIzol reagent $(\mathrm{M} / \mathrm{s}$ Invitrogen, USA), 10X Taq buffer, $10 \mathrm{mM}$ dNTPs mix, Taq DNA polymerase $(6 \mathrm{U} / \mathrm{mL})(\mathrm{M} / \mathrm{s}$ Biotools, Spain), Agarose (M/s Amresco, USA), 6x loading dye, molecular size quantitative marker (M/s Fermentas, USA), 5x tris Boric acid EDTA buffer. cDNA synthesis kit (RevertAid $^{\mathrm{TM}}$ First Strand cDNA synthesis Kit, Fermentas Life Sciences), Real- time SYBR Green qPCR kit (DyNAmo ${ }^{\mathrm{TM}} \mathrm{HS}, \mathrm{M} / \mathrm{s}$ Finnzymes, USA.

Hatching of experimental chicks: Fertile eggs were collected at Experimental Broiler Farm for incubation. Total of 36 chicks (three weeks old) of CARIBROMritunjai, CARIBRO-Tropicana and CARIBROVishal each, for each exposure trial were used.

Management of chicks: The chicks were reared up to 3 weeks of age at Experimental Broiler Farm (EBF) under uniform nutrition (Table-1) and management. The chicks were reared at litter with ad lib feeding of starter ration (Table-1). At three weeks of age the chicks were shifted to Psychometric chamber, Veterinary Physiology Division, IVRI, Izatnagar, for exposure under particular THI for a period of 7 days. Three weeks old chicks (36) of each germplasm were used in this study in each exposure trial totaling to 108 chicks of each genetic group in the three exposure trials and 324 chicks of all genetic groups in all exposure trials.

Thermal humidity index (THI) exposures for evaluation of broiler stocks: The evaluation of these stocks was carried out at three different THI in three separate trials. The birds of each genetic groups were kept in Psychometric chamber at an age of 3 week and the chamber was set to provide specific temperature and humidity for a particular THI. The desired temperature and humidity at each THI were provided for a 
period of 4 hours daily for experimental duration of 7 days.

THI 1 (72): Temperature: $23 \pm 1^{\circ} \mathrm{C}$ and Relative humidity: $40 \pm 5 \%$ (Zone of comfort)

THI 2 (85): Temperature: $35 \pm 1{ }^{\circ} \mathrm{C}$ and Relative Humidity: $50 \pm 5 \%$ (Mild stress)

THI 3 (91): Temperature: $41 \pm 1{ }^{\circ} \mathrm{C}$ and Relative Humidity: $45 \pm 5 \%$ (High stress)

THIs were determined using following formula [13]:

Where,

$$
\mathrm{THI}=\mathrm{T}_{\mathrm{d}^{-}}(0.55-0.55 \mathrm{RH})\left(\mathrm{T}_{\mathrm{d}}-58\right)
$$

$\mathrm{T}_{\mathrm{d}=}$ Dry- bulb temperature in ${ }^{\circ} \mathrm{F}$

$\mathrm{RH}=$ Relative Humidity in \% (In equation, RH is used as a decimal; in other words, $50 \%$ relative humidity is indicated as 0.50 .

Organization of exposure trial: The chicks of each genetic group were simultaneously exposed to particular THI and different parameters were recorded. The chicks (3 week old) of each genetic group were housed in battery brooders inside the Psychometric chamber. The battery brooders were consisted of 4 tiers and two compartments in each tier. Each compartment housed 7-8 chicks. Thus, a total of 36 chicks of one genetic group were housed in 5 compartments of battery brooder.

Molecular analysis: Expression profile analysis of HSP-70 in liver tissue at $0^{\text {th }}, 3^{\text {rd }}$ and $7^{\text {th }}$ day of experiment.

Sample size: A sample of 4 birds/ genetic groups/ experimental day was slaughtered soon after THI exposure (i.e. 4 hours daily on a particular THI) under each THI exposure and liver tissues were collected for HSP-70 gene expression analysis.

HSP 70 gene expression studies: Total RNA was isolated from the liver following standard TRIZOL method. The purity of RNA was checked before the preparation of first- strand cDNA. Prepared cDNA was stored frozen at $-20^{\circ} \mathrm{C}$ and was used for HSP 70 gene expression studies. Expression of HSP 70 gene was quantified by using specific primer pairs for genes of interest (GOI) in Real-Time PCR. Here $\beta$-actin was used as a reference gene and $0^{\text {th }}$ day sample after exposure was taken as control.

Sterilization and inactivation of RNases: Glasswares used for RNA work were sterilized in hot air oven at $180^{\circ} \mathrm{c}$ for at least 5 hours to make them RNase free. All the plasticwares used for the same purpose were thoroughly treated with $0.1 \%$ Diethyl pyrocarbonate (DEPC) at $37^{\circ} \mathrm{C}$ for about $12 \mathrm{hr}$ in order to destroy the RNases and then were sterilized by autoclaving.

I solation of total RNA: The tissue samples from liver were cut into small pieces and collected in $2 \mathrm{ml}$ RNase free microcentrifuge tubes containing $600 \mu \mathrm{l}$ TRIzol (M/s Invitrogen, USA) denaturing solution. The tissue sample were homogenized using tissue homogenizer at
$2000 \mathrm{rpm}$ perform for about 30 seconds till a uniform suspension is formed. One hundred and twenty microliter $(120 \mu \mathrm{l})$ of chloroform (molecular biology grade) was added into the tube and was thoroughly mixed. The tissue suspension was centrifuged at 13000 $\mathrm{rpm}$ for $15 \mathrm{~min}$ at $4^{\circ} \mathrm{C}$ in micro-centrifuge (KUBOTA3500, Japan). The top aqueous phase (containing RNA) was removed and transferred carefully into a fresh $1.5 \mathrm{ml}$ RNase free micro-centrifuge tube without disturbing pellet. Equal volume of isopropanol was added to the aqueous phase and incubated at room temperature $\left(25^{\circ} \mathrm{C}\right)$ for $20 \mathrm{~min}$ to precipitate the RNA. The RNA was pelleted by spinning at $10000 \mathrm{rpm}$ for 10 $\min$ at $4^{\circ} \mathrm{C}$; thereafter the isopropanol supernatant was decanted carefully without disturbing the pellet. The pellet was washed with $0.5 \mathrm{ml}$ of $70 \%$ ice-cold ethanol and the tube was centrifuged at $10000 \mathrm{rpm}$ for $10 \mathrm{~min}$ at $4^{\circ} \mathrm{C}$. The ethanol was decanted and the RNA pellet was air dried in an RNase free environment. The air dried RNA pellet was re-suspended in $50 \mu 1$ of nuclease free water.

RNA quantification: The purity and concentration of the total RNA was checked using nanodrop (Nano Drop1000, Thermo Scientific, Singapore). The purity of the total RNA was confirmed by considering the ratio of OD values at 260 and $280 \mathrm{~nm}$. The purity was further checked by Agarose gel electrophoresis. The RNA showing any contamination with DNA was incubated with RNase free DNase (Biogene, CA USA) at $37^{\circ} \mathrm{C} @ 1 \mathrm{U}$ for $\left.1 \mu \mathrm{l}\right)$. The DNase was subsequently inactivated by incubation at $65^{\circ} \mathrm{C}$ for $10 \mathrm{~min}$. Each DNase treated total RNA sample was computed and all the samples were adjusted to equal concentration (5.0 $\mu \mathrm{g} / \mu \mathrm{l})$.

First- strand c DNA synthesis: The first-strand cDNA synthesis was carried out using $200 \mu \mathrm{l}$ PCR microtubes in a thermal block using Revert Aid ${ }^{\text {TM first }}$ strand cDNA synthesis kit (MBI, Fermantas). Eleven micro-liters $(11 \mu \mathrm{l})$ diluted total RNA (containing $5.0 \mu \mathrm{g}$ of RNA) was taken in RNase free PCR tube $(0.2 \mathrm{ml})$. One microliter $(1 \mu \mathrm{l})$ of random hexamer primer $(0.5 \mu \mathrm{g} / \mu \mathrm{l})$ was added to each RNA samples and spinned down for few seconds. Each tube containing $12 \mu \mathrm{l}$ of reaction mixture was incubated $65^{\circ} \mathrm{C}$ for 5 minutes in thermal cycler. Eight micro liters of master mix containing $5 \mathrm{X}$ reaction buffer $(4 \mu \mathrm{l}), 10 \mathrm{mM}$ dNTP mix $(2 \mu \mathrm{l})$, Ribonuclease inhibitor $(1 \mu \mathrm{l})$ and revert $\mathrm{Aid}^{\mathrm{TM}}$ reverse transcriptase $(1 \mu \mathrm{l})$ was added to each tube and mixed thoroughly. The total reaction mixture was incubated in the thermal cycler according to the manufacturer's instructions i.e. $25^{\circ} \mathrm{C}$ for $5 \mathrm{~min}$ and $42^{\circ} \mathrm{C}$ for 60 minutes. Finally, the reaction was stopped by heating at $70^{\circ} \mathrm{C}$ for $10 \mathrm{~min}$ and the resultant first-strand c-DNA was synthesized and stored at $-20^{\circ} \mathrm{C}$ till further expression studies.

HSP-70 mRNA quantification: The relative expression of specific gene mRNA was quantified by real-time PCR detection system (IQ5, Bio- Rad laboratories Inc. USA). All reactions were performed in nuclease-free 8 
Table-2. Details of the primers used for real-time PCR analysis of HSP-70 gene in liver tissue of broiler chickens during different stress conditions (THIs).

\begin{tabular}{lllccc}
\hline Sr no. & Genes & Primer & Annealing Temperature & Product size (bp) & Accession number \\
\hline 1 & HSP- 70 & F-GGCACCATCACTGGCTT & $56{ }^{\circ} \mathrm{C}$ & 74 & Hm587997 \\
2 & \multirow{2}{*}{ R-actin } & $\begin{array}{l}\text { R-TCCAAGCCATAGGCAATAGCA } \\
\text { F-GGAGTTACTCGCCTCTG }\end{array}$ & & & \\
& & R-AAGACACTTGTTGGGTTAC & $58 ? \mathrm{C}$ & 114 & L08165 \\
\hline
\end{tabular}

$\mathrm{F}=$ Forward; $\mathrm{R}=$ Revel

- Standard $\boldsymbol{x}$ Unknown

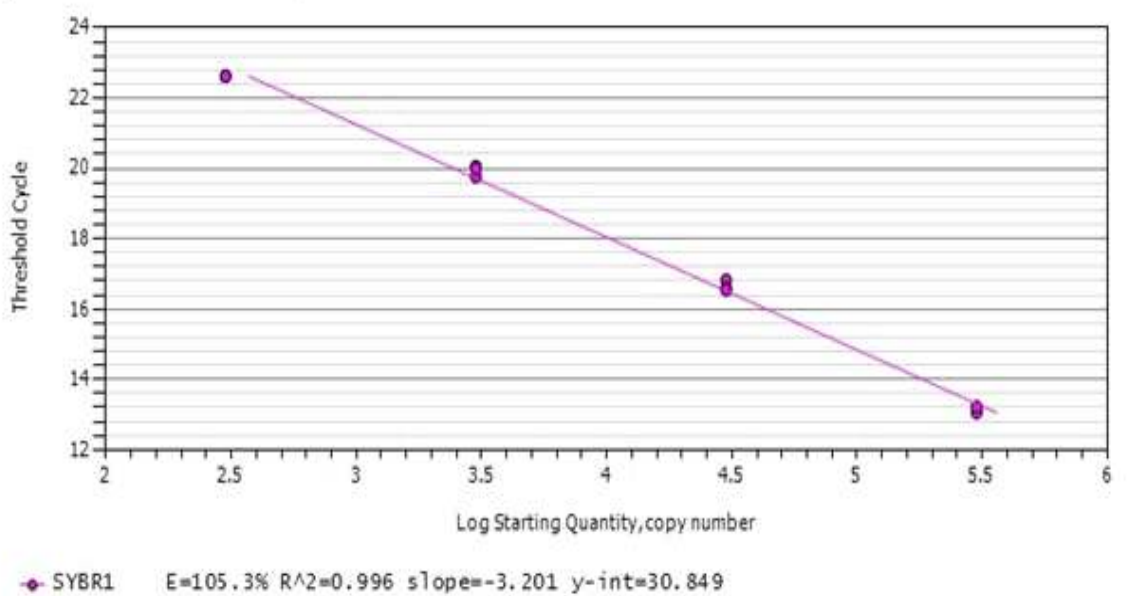

PCR Standard Curve :

b-act. SLOPE

Figure-1. PCR standard curve of $\beta$-actin gene slope

tubes with optically clear flat caps (Axygen Scientific, Inc. USA).

Real- time polymerase chain reaction: Twenty microliter volume of reaction mixture was used to amplify the gene of interest with final concentration of $1 \mathrm{X}$ SYBR Green PCR master mix (2x DyNAmo ${ }^{\mathrm{TM}} \mathrm{HS}$, Finnzymes, USA) which contain SYBR Green 1dye, Meteor Taq hot start DNA polymerase, dNTPs including dUTP and $\mathrm{MgCl}_{2}$ with $4 \mathrm{M}$ final concentration in optimized buffer components, a $0.05 \mathrm{pM}$ concentration of gene-specific primer (Table-2) and $2.5 \mu$ l of diluted (1:10) cDNA template. Real-time PCR cycling conditions were, initial denaturation at $95^{\circ} \mathrm{C}$ for $20 \mathrm{~s}$, annealing at $56^{\circ} \mathrm{C}$ or $58^{\circ} \mathrm{C}$ for different gene for 20 s and extension $72{ }^{\circ} \mathrm{C}$ for 20 s. For each sample a dissociation curve (melt curve) was generated after completion of amplification. A negative control containing all the ingredients except cDNA template (Non-template control; NTC) was set up invariably for each master mix made for conducting the reactions. $\beta$ actin was used as reference gene. The results were expressed in terms of the threshold cycle value $(\mathrm{Ct})$. PCR standard curve of $\beta$-actin gene is given in fig. -1 . Melt peak chart of HSP-70 and $\beta$-actin gene is given in fig. -2 .

Statistical analysis: The data generated under the present investigation were analysed using SPSS ver 16. The data were classified according to genetic groups and THIs. Analysis of data on these parameters was performed using a fixed model with genetic groups and THI as main effects under each day of experiment. All data were presented in Tables as Mean + Standard error mean. The data recorded as CT values for gene expression analysis of HSP-70 gene was also analysed as per below models.

$\mathrm{Y}_{\mathrm{ijk}}=\mu+\mathrm{G}_{\mathrm{i}}+\mathrm{T}_{\mathrm{j}}+(\mathrm{GxT})_{(\mathrm{ij})}+\mathrm{e}_{\mathrm{ijk}}$

where, $\mathrm{Y}_{\mathrm{ijk}}=$ Trait recorded under $\mathrm{i}^{\text {th }}$ genetic group and $\mathrm{j}^{\text {th }} \mathrm{THI}$ on $\mathrm{k}^{\text {th }}$ individual

$\mu=$ Overall mean

$\mathrm{G}_{\mathrm{i}}=$ Effect of $\mathrm{i}^{\text {th }}$ genetic $\operatorname{group}(\mathrm{i}=1,2,3)$

$\mathrm{T}_{\mathrm{j}}=$ Effect of $\mathrm{j}^{\text {th }} \mathrm{THI}(\mathrm{j}=1,2,3)$

$(\mathrm{G} \times \mathrm{T})_{(\mathrm{ij})}=$ Interaction effect between $\mathrm{i}^{\text {th }}$ genetic group and $j^{\text {th }}$ THI

$\mathrm{e}_{\mathrm{ij \textrm {k }}}=$ Random error distributed with mean ' 0 ' and variance' $\sigma^{2}$,

\section{Results}

The mean mRNA expression levels of HSP-70 in liver of birds of three genetic groups at $0^{\text {th }}, 3^{\text {rd }}$ and $7^{\text {th }}$ days of experiment under different THIs have been presented in Table-3 and Fig.3. The difference among three genetic groups were significant $(\mathrm{P}<0.05)$ at $0^{\text {th }}, 3^{\text {rd }}$ and $7^{\text {th }}$ day of experiment at THI 72, 85 and 91. The higher mRNA expression levels of $H S P-70$ at all the time points under different THIs were exhibited in CARIBRO-Tropicana $(1.27 \pm 0.01$ to $2.51 \pm 0.019)$ as compared to CARIBRO-Vishal $(1.037 \pm 0.016$ to $2.118 \pm 0.020)$ and CARIBRO-Mritunjai (1.164 \pm 0.005 to $2.321 \pm 0.010)$ (Table-3). CARIBRO-Tropicana (2.379 \pm 0.007$)$ exhibited higher expression of HSP-70 on $0^{\text {th }}$ day than CARIBRO-Mritunjai (2.219 \pm 0.010$)$ and CARIBRO-Vishal $(1.993 \pm 0.025)$ at THI 91. CARIBRO-Vishal (1.037 \pm 0.016$)$ exhibited lower

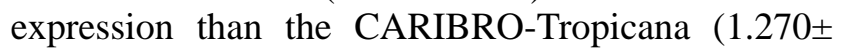




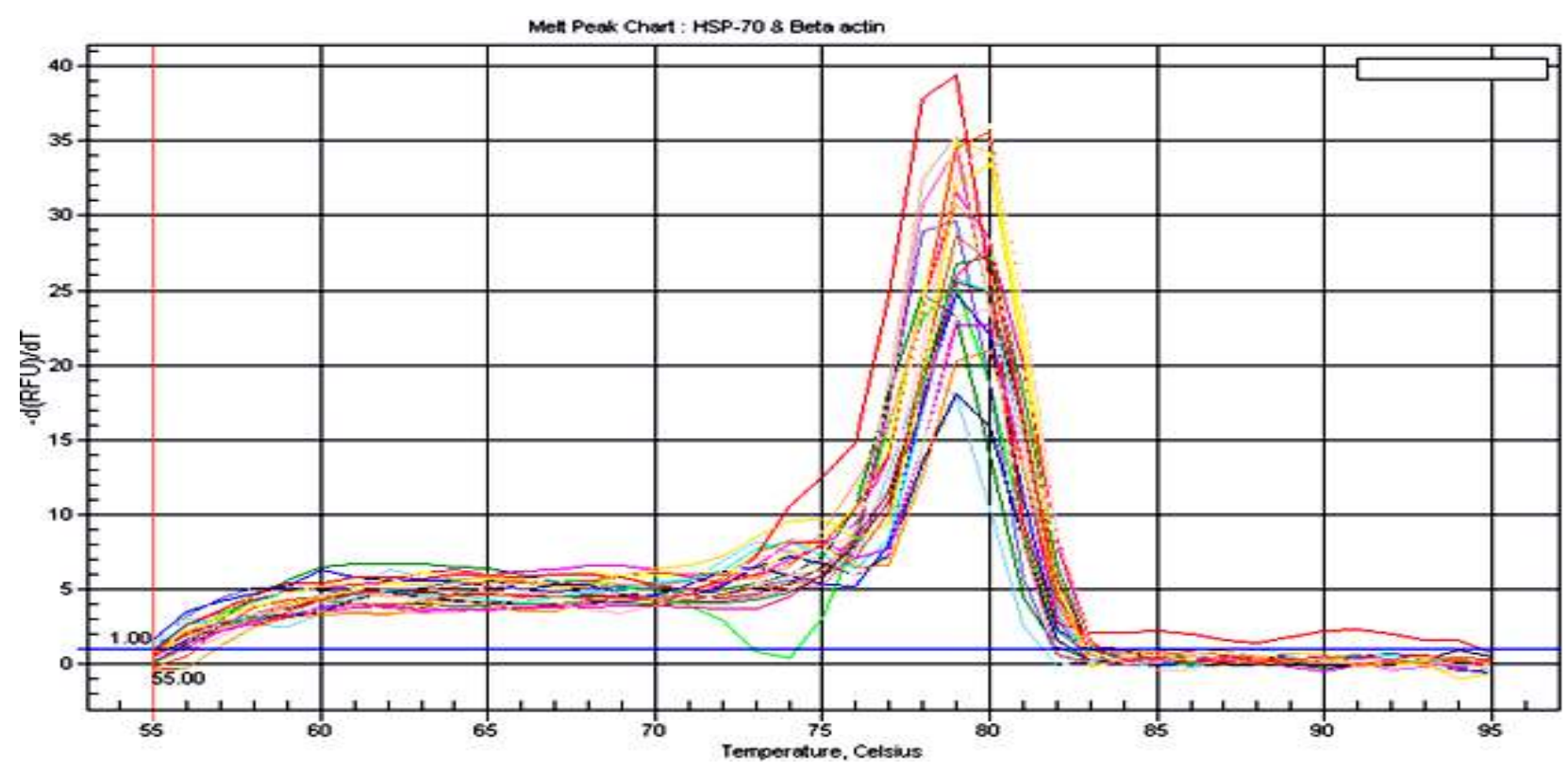

Figure-2. Melt peak chart (Dissociation curve) of HSP-70 and $\beta$-actin gene

Table-3. mRNA expression profile of heat shock protein-70 gene in liver of broiler chicken of different genetic groups at different days during experimental period under different THI (Mean \pm SE)

\begin{tabular}{llllll}
\hline Day of experiment THI & CARIBRO-Tropicana (T1) & CARIBRO-Mritunjai (T2) & CARIBRO- Vishal (T3) & Overall mean \\
\hline Oth day & THI $<72$ & $1.270^{\mathrm{aA}} \pm 0.011(4)$ & $1.164^{\mathrm{bA}} \pm 0.005(4)$ & $1.037^{\mathrm{CA}} \pm 0.016(4)$ & $1.157 \pm 0.007(12)$ \\
(After Exposure) & THI85 & $1.744^{\mathrm{aB}} \pm 0.006(4)$ & $1.675^{\mathrm{bB}} \pm 0.011(4)$ & $1.529^{\mathrm{CB}} \pm 0.022(4)$ & $1.649 \pm 0.008(12)$ \\
& THI91 & $2.379^{\mathrm{aC}} \pm 0.018(4)$ & $2.219^{\mathrm{bC}} \pm 0.010(4)$ & $1.993^{\mathrm{CC}} \pm 0.025(4)$ & $2.197 \pm 0.011(12)$ \\
\multirow{3}{*}{ 3rd day } & Overall mean & $1.798 \pm 0.007(12)$ & $1.686 \pm 0.005(12)$ & $1.520 \pm 0.012(12)$ & \\
& THI $<72$ & $1.290^{\mathrm{aA}} \pm 0.015(4)$ & $1.199^{\mathrm{bA}} \pm 0.010(4)$ & $1.087^{\mathrm{CA}} \pm 0.016(4)$ & $1.192 \pm 0.008(12)$ \\
& THI85 & $1.821^{\mathrm{aB}} \pm 0.013(4)$ & $1.720^{\mathrm{bB}} \pm 0.008(4)$ & $1.564^{\mathrm{CB}} \pm 0.008(4)$ & $1.702 \pm 0.005(12)$ \\
& THI91 & $2.433^{\mathrm{aC}} \pm 0.011(4)$ & $2.266^{\mathrm{bC}} \pm 0.008(4)$ & $2.025^{\mathrm{CC}} \pm 0.014(4)$ & $2.241 \pm 0.009(12)$ \\
7 th day & Overall mean & $1.848 \pm 0.007(12)$ & $1.729 \pm 0.005(12)$ & $1.559 \pm 0.10(12)$ & \\
& THI $<72$ & $1.315^{\mathrm{aA}} \pm 0.012(4)$ & $1.239^{\mathrm{bA}} \pm 0.014(4)$ & $1.123^{\mathrm{CA}} \pm 0.009(4)$ & $1.226 \pm 0.007(12)$ \\
& THI85 & $1.863^{\mathrm{aB}} \pm 0.008(4)$ & $1.762^{\mathrm{bB}} \pm 0.006(4)$ & $1.591^{\mathrm{CB}} \pm 0.014(4)$ & $1.739 \pm 0.006(12)$ \\
& THI91 & $2.510^{\mathrm{aC}} \pm 0.019(4)$ & $2.321^{\mathrm{bC}} \pm 0.010(4)$ & $2.118^{\mathrm{cC}} \pm 0.020(4)$ & $2.316 \pm 0.010(12)$ \\
& Overall mean & $1.896 \pm 0.008(12)$ & $1.775 \pm 0.006(12)$ & $1.611 \pm 0.009(12)$ & \\
\hline
\end{tabular}

1) Figures in parentheses are the number of observations; 2) Figure bearing same superscript (lower case) in a row and (upper case) in a column within day of experiment do not differ significantly $(\mathrm{P}<0.05)$; 3 ) The figures bearing different superscript (symbol) differ significantly in a particular THI during different days in a column.

$0.011)$ and CARIBRO-Mritunjai $(1.164 \pm 0.005)$ at THI 72 on $0^{\text {th }}$ day. CARIBRO-Tropicana $(1.744 \pm 0.006)$ exhibited higher expression than CARIBRO-Mritunjai $(1.675 \pm 0.011)$ and CARIBRO-Vishal $(1.529 \pm 0.022)$ on $0^{\text {th }}$ day at THI 85 . The effect of THI was also found significant $(\mathrm{P}<0.05)$ on mRNA expression of HSP-70 at different days of experiment in each of the genetic groups (Table-3). The mRNA expression levels of HSP-70 were significantly $(\mathrm{P}<0.05)$ higher at THI 91 than at THI 72 and 85 in each genetic groups. Significantly lower $(\mathrm{P}<0.05)$ mRNA expression of $H S P-70$ was observed on $0^{\text {th }}$ day $(1.744 \pm 0.006)$ than at $3^{\text {rd }}$ day $(1.863 \pm 0.008)$ under THI 85 in CARIBROTropicana. mRNA expression of HSP-70 in CARIBRO-Tropicana under THI 91 was observed significantly lower at $0^{\text {th }}$ day $(1.821 \pm 0.013)$ than at $3^{\text {rd }}$ day $(2.379 \pm 0.018)$ and $7^{\text {th }}$ day $(2.51 \pm 0.019)$. In CARIBRO-Mritunjai, mean mRNA expression of $H S P-70$ was observed significantly lower on $0^{\text {th }}$ day $(1.675 \pm 0.011)$ than $3^{\text {rd }}$ day $(1.720 \pm 0.008)$ and $7^{\text {th }}$ day $(1.762 \pm 0.006)$ of experiment under THI 85. Under THI
91, mean mRNA expression of $H S P-70$ was observed significantly lower on $0^{\text {th }}$ day $(2.219 \pm 0.010)$ than $3^{\text {rd }}$ day $(2.266 \pm 0.008)$ and $7^{\text {th }}$ day $(2.321 \pm 0.010)$ in CARIBRO-Mritunjai. In CARIBRO-Vishal, mRNA expression of $H S P-70$ was observed significantly lower on $0^{\text {th }}$ day $(1.529 \pm 0.022)$ than $3^{\text {rd }}$ day $(1.564 \pm$ $0.008)$ and $7^{\text {th }}$ day $(1.591 \pm 0.014)$ of experiment under THI 85. Under THI 91, mRNA expression of HSP-70 was observed significantly lower on $0^{\text {th }}$ day $(1.993 \pm$ $0.025)$ than $3^{\text {rd }}$ day $(2.025 \pm 0.014)$ and $7^{\text {th }}$ day $(2.118 \pm$ 0.020) in CARIBRO-Vishal (Table-3). Under THI-85 and THI-91, the m-RNA expression of HSP-70 in group was significantly lower at $0^{\text {th }}$ day in comparison to $3^{\text {rd }}$ day and $7^{\text {th }}$ day of experiment (Table-3 and Fig. 3.).

\section{Discussion}

mRNA expression of HSP-70 in different broiler stocks/genotypes under different stress conditions have been reported by [14-19] mRNA expression in CARIBRO-Tropicana (1.23) at $7^{\text {th }}$ day after exposure at $23^{\circ} \mathrm{C}$ were comparable to those reported by Shoaib 


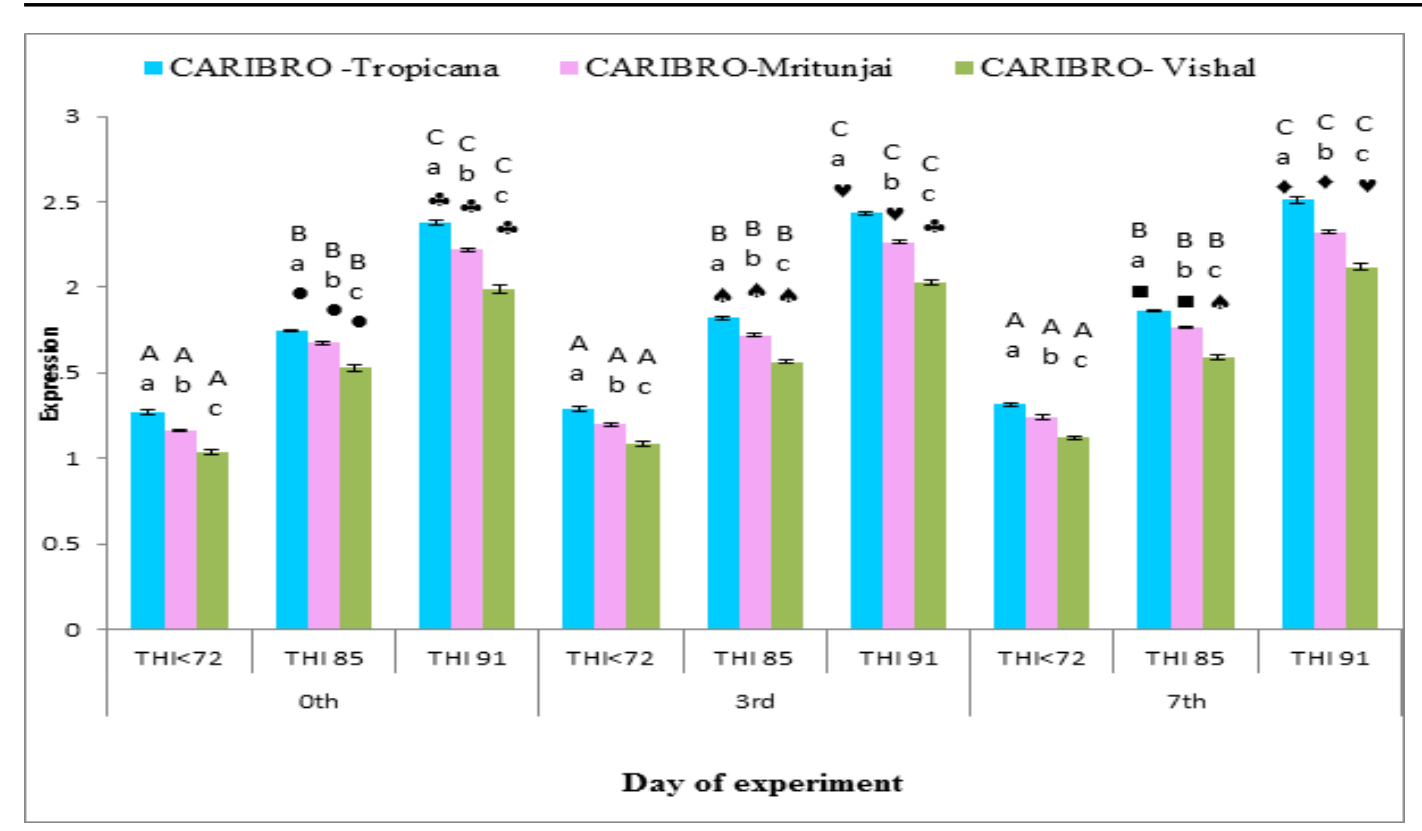

1) Figures bearing same superscript (lower case) do not differ significantly $(P \leq 0.05)$ among genetic groups within THI.

2) Figures bearing same superscript (upper case) do not differ significantly ( $\mathrm{P}<0.05)$ among different $\mathrm{THI}$ within genetic groups and within day of experiment.

Figure-3. mRNA expression profile of heat shock proteins- 70 gene in liver of broiler chickens of different genetic groups at different days during experimental period under different THI (Mean \pm SE)

[19], in 3 weeks male of CARIBRO-Vishal at $23^{\circ} \mathrm{C}$. In the present investigation, the differences in mRNA expression of $H S P-70$ among genetic groups under different THIs for different days were significant. The effect of THI was found significant on mRNA expression of $H S P-70$ at different days and different genetic groups. Significant effect at higher ambient temperature on mRNA expression of $H S P-70$ in broilers have also been reported in literature [14-19].

Day-wise differences also occurred in CARIBRO-Tropicana, CARIBRO-Mritunjai and CARIBRO-Vishal under THI 85 and 91. Role of HSPs in general and HSP-70 in particular in thermotolerance/stress and under infectious conditions is well documented in poultry and other animal species [20]. The increment in mRNA expression in broiler chickens under heat stress highlighted the role of $H S P-70$ in the protection of cells from heat stress. An important aspect of $H S P-70$ is that cells or organisms those have reversed from a previous mild stressful condition express elevated levels of stress proteins. These stress proteins $(H S P-70)$ can exhibit tolerance against the high doses of the stress causing agents, including heat that would normally cause developmental abnormalities or death. This phenomenon referred to as acquired thermotolerance has been shown to be dependant on the increased expression and accumulation of the HSP70 [11].

\section{Conclusion}

The differences due to THI and genetic groups were found significant for $H S P-70$ traits studied. During the 7 day exposure trial, birds of all the three genetic groups exhibited the phenomenon of acclimatization as reveled by the averages of various traits at different days into the exposure. Among the three genetic groups, CARIBRO-Tropicana exhibited highest means for $H S P-70$ production as well as tolerated the heat stress in a better way than CARIBRO-Mritunjai and CARIBRO-Vishal; therefore CARIBRO-Tropicana was adjudged to be the best genetic group for production under tropical climate.

\section{Authors' contributions}

SAA, VKS and SM: Substantially contributed to the conception and design of study. SAA and VKS: Drafted the manuscript, analysed and interpreted the results. SAA and SM: Carried out the laboratory works, revised manuscript for important intellectual content. All authors read and approved the final manuscript.

\section{Acknowledgements}

The authors are thankful to the authorities of the Department of AGB, CARI, Izzatnagar, U.P. India, for leasing out the department's poultry house and equipment to carry out this investigation. No outside fund was received for this study. Some fund was contributed by authors.

\section{Competing interests}

The authors declare that they have no competing interests.

\section{References}

1. Havenstein, G. B., Ferket, P. R., Schiedeler, S. E. and Lorson, B. T. (1994) Growth, livability and feed conversion of 1991 vs 1957 broilers when fed typical 1957 and 1991 broiler diets. Poultry Sci., 73: 1785- 1794.

2. Havenstein, G. B., Ferket, P. R. and Qureshi, M. A. (2003 a) Growth, livability and feed conversion of 1957 versus 2001 broilers when fed representative 1957 and 2001 broiler diets. Poultry. Sci., 82: 1500-1508.

3. Havenstein, G. B., Ferket, P. R., and Qureshi, M. A. (2003b) Carcass composition and yield of 1957 versus 2001 broilers when fed representative 1957 and 2001 broiler diets. Poultry. Sci., 82:1509-1518.

4. Janke, O., Tzschentke, B. and Boerjan, B. (2004) Comparative investigation of heat production and body temperature in modern chicken breeds. Avian Poultry Biol Rev 15 : 191-196. 
5. Lindquist, S. (1992) Heat- shock proteins and stress tolerance in microorganisms. Curr Opin Genet Dev. 2: 74855.

6. Lindquist, S. and Craig, E. A., (1988) The heat shock proteins. Ann. Rev.Genet. 22:631-77.

7. Merat, P. (1986) Potential usefulness of the Na (naked neck) gene in poultry production. World Poultry Sci J., 42: 124142.

8. Cahaner, A. and Leenstra, F. (1992) Reduced heat tolerance in fast growing broilers. Poultry Sci., 71: 237-250.

9. Burdon R. H. (1986). Heat shock and heat shock proteins. Biochem. J., 240 (2): 313-324.

10. Welch, M. J. and Mizzen, L. A. (1988) Characterizationof the thermotolerant cell. II. Effects on the intracellular distribution of heat shock proteins 70 intermediate filaments and small nuclear ribonucleo protein complexes. J. Cell. Biol., 106: 1117-1130.

11. Henle, K. J. and Leeper, D. B. (1982) Modification of heat response and thermotolerance by cycloheximide, Hydroxyurea and Lucanthone in CHO cells. Radiat. Res., 90: 339-347.

12. Young, R. A. (1990) Stress proteins and Immunology. Ann. Rev. Immunol., 8: 401-420.

13. Frank Wiersama (1990) Dep. Agric. Eng. University of Arizona, Tuscon, Arizona, USA.

14. Givisiez, P. E. Ferro, J. A., Kronka, S. N. (2001) Hepatic concentration of heat shock proteins $70 \mathrm{kd}$ (HSP-70) in broilers subjected to different thermal treatments. Br. Poultry Sci 40:292-96.

15. Maak, S., Melesse, A., Schmidt, R., Schneider, F. (2003) Effect of long term heat exposureon peripheral concentrations of HSP-70 and hormones in laying hens with different genotypes. Br. Poultry Sci 44:133-38.

16. Guerreiro, E. N., Glacnetto, P. F., Givisiez, P. E., Ferro, J. A. (2004) Brain and hepatic HSP-70 protein levels in heat acclimated broiler chickens during heat stress. Braz. J. Poultry Science. 6(4): 201- 206.

17. Nadja, S. M. Elizabeth, G., Jesus, A. (2004) Expression of HSP in broiler embryo tissue after acute cold or heat stress. Faculdade de veterinaria e Zootecnia, UNESP, Sao PAULO, Brazil.40:292-96.

18. Das, S., Pan, D., Bera, A. K., Rana, T. (2009) Stress inducible HSP-70: a potent molecular and signature in arsenic exposed broiler chickens. Mol. Biol. Rep. 36(8): 435-45.

19. Shoaib, A. (2011) Expression of HSP-70 in GIT and its correltion with nutrient uptake and digestive enzymes in stressed chicken, Ph. D. thesis, IVRI, Izatnagar, p. 153.

20. Siegel, H. S. (1995) Stress, strains and resistance. Br. Poultry Sci 36: 03-22.

21. Hisaeda, H., Sakai, T., Ishikawa, H., Maekawa, Y., Yasutomo, K., Good, R. A. and Imeno, K. (1997) Heat shock protein-65 induced $\mathrm{gd} \mathrm{T}$ cells prevent apoptosis of macrophages and contributes to host defence in mice infected with toxoplasma gondii. J. Immunol. 159:23752381.

22. Tu, Yun-jie, Chen, Guo-hong, Geng, Zhao-yu, Su, Yi-jan, Wang, Ke-hua. (2010) The expression of HSP-70 mRNA in hypothalamic pituitary Thyroid axis under cold stress

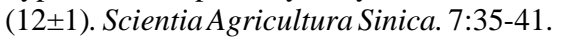

23. Soleimani, A. F., Zulkifli, I., Omar, A. R. and Raha, A. R. (2011) Neonatal feed restriction modulates circulating levels of corticosterone and expression od glucocorticoid receptor and heat shock protein 70 in aged Japanese quail exposed to acute heat stress. Poultry Sci. 90(7) :1427-1434.

24. Tu, Yun-jie, Chen, Guo-hong, Geng, Zhao-yu, Su, Yi-jan, Wang, Ke-hua. (2010) The expression of HSP-70 mRNA in hypothalamic pituitary Thyroid axis under cold stress (12 \pm 1$)$. Scientia Agricultura Sinica. 7:35-41.

25. Shit, N. G. (2010) Molecular approaches for the evaluation of stress and its amelioration on ovarian functions in Japanese quails (Coturnix coturnis japonica) Ph.D. thesis, Deemed University, IVRI, Izatnagar, India.

26. Zulkifli, I. Al-Aqil, A., Omar, A. R., Sazili, A. Q. and Rajan, M. A. (2009) Crating and stress influence blood parameters and heat shock protein 70 expression in broiler chickens showing short or long tonic immobility reactions. Poultry Sci. 88:471-476.

27. Sahin, N., Tuzcu, M. Orhan, C., Onderchi, M., Eroksuz, Y. and Sahin, K. (2009) The effect of Vitamin- c and E supplementation on heat shock protein 70 response of ovary and brain in heat stressed quail. Br. Poultry Sci. 50 (2):259265.

28. Das, S., Pan, D., Bera, A. K., Rana, T. (2009) Stress inducible HSP-70: a potent molecular and signature in arsenic exposed broiler chickens. Mol. Biol. Rep. 36(8):43545.

29. Al-Aqil, A. andZulkifli, (2009) Changes in the heat shock protein 70 expression and blood characteristics in transported broiler chickens as affected by housing and early age feed restriction. Poultry Sci. 88:1358-1364.

30. Sun, Pei-ming, Liu, Yu-Tian, Wang, Quing-Hua, Wang, Zhiliang, Bao, Endong. (2007) Localization of HSP-70 and HSP-70 mRNA in the tissues of heat stressed broilers. J. Agr. Biotechnol.3:102-107.

31. Rafael, E. R., Christensen, V. L., Edens, F. W. and Wineland. M. J. (2005) The effect of selenium on heat shock [proteins 70 expressions in Turkey embryos (Meleagris gallopavo). Comp Biochem Physiol Mol Integr Physiol 142:427-432.

32. Figueiredo, D., Getrler, A., Cabello, G., Decuypere, E., Buyse, J. and Dridi, S. (2007) Leptin down regulates heat shock protein- 70 (HSP70) gene expression in chicken liver and hypothalamus. Cell Tissue Res 329: 91-101.

33. Maak, S., Melesse, A., Schmidt, R., Schneider, F. (2003) Effect of long term heat exposureon peripheral concentrations of HSP-70 and hormones in laying hens with different genotypes. Br. Poultry Sci. 44:133-38.

34. Givisiez, P. E. Ferro, J. A., Kronka, S. N. (2001) Hepatic concentration of heat shock proteins $70 \mathrm{kd}$ (HSP-70) in broilers subjected to different thermal treatments. Br. Poultry Sci. 40:292-96.

35. Gabriel, J. E., Ferro, M., Ferro, J. A., Givisiez, P. and Macari, M. M. (2000) Influence of dietary energy level on hapatic 70 Kda heat shockprotein expression in broiler chickens submitted to acute heat stress. Revist. Brasil. De.Cian. Avicol.2(3):102-109.

36. Mahmoud, K. Z., Edens, F. W., Eisen, E. J. and Havenstein, G. B. (2003) Effect of ascorbic acid and acute heat exposure on the heat shock protein 70 expression by young white Leghorn chickens. Comp Biochem Physiol C Toxicol Pharmacol, 136: 329-339.

37. Pelham, H. R. B. (1986) Speculation on the functions of the Major heat shock and glucose regulated proteins. Cell, 46: 959-961.

38. Randall, L. L. and Hardy, S. J. (1986) Correlations of competence for export with lack of tertiary structure of the manure species: a study in vivo of maltose binding protein in E. coli. Cell, 46: 921-928.

39. Murukami, H. K., Pain, D. and Blobel, G. (1988) 70- kDa heat shock related protein in chicken reticulocytes and lymphocytes. J. Cell. Biol. 107: 2051- 2057.

40. Wang, S. and Edens, F. W. (1998) Heat conditioninginduces heat shock proteins in broiler chickens and turkey poults. Poultry Sci,. 77: 1636-1645. 